\title{
The Development of International Education towards Migration Abroad by Indonesian Women
}

\author{
Muhammad Zid $^{1, *}$, Asep Rudi Casmana ${ }^{2}$, Sony Nugratama Hijrawadi ${ }^{1}$ \\ ${ }^{1}$ Department of Geography Education, Faculty of Social Science, Universitas Negeri Jakarta, Indonesia \\ ${ }^{2}$ Department of Pancasila and Citizenship Education, Faculty of Social Science, Universitas Negeri Jakarta, Indonesia
}

Received February 22, 2020; Revised March 28, 2020; Accepted April 19, 2020

Copyright $\mathrm{C} 2020$ by authors, all rights reserved. Authors agree that this article remains permanently open access under the terms of the Creative Commons Attribution License 4.0 International License

\begin{abstract}
The study aimed to determine the degree of empowerment education towards ex-migrant women in the economic field, to explore the use of remittance sent by emigrant women to their families, and to identify the role of ex-migrant women to educate the community. A mixed-method research approach was used to obtain comprehensive information with questionnaire and in-depth interview with 45 participants. The research was undertaken in Subang, West Java, Indonesia, which was chosen due to the large number of Indonesian workers. The results of the study showed that women, who have migrated overseas for work, obtained a lot of international education experience, especially in terms of economic empowerment, and as a result were able to undertake economic activities upon returning to their home, such as opening a small food stall, and working in small to medium enterprises making and selling handicrafts as well as teaching Arabic language. The research also showed that the use of remittance by the families of ex-migrant women generally takes the form of material (economic) for day-to-day need, tuition fee and investment. The research concluded that ex-migrant women appear to gain international education experience, economic and social empowerment and have a willingness to educate and share their experience in community activities such as mutual cooperation, social gathering, and also in Posyandu (local health center) activities. Continuous investment in skills has not been done entirely by ex-migrant women. The results of working abroad are still used to meet daily needs.
\end{abstract}

Keywords Ex-Migrants, International Education Experience, Empowerment of Women, Remittances

\section{Introduction}

Migration is considered to be the act of people to move from one area to others and it could be moving across the country. Usually, it takes place from people leaving in developing countries and move to developed nations (Hamano, 2014). They leave their home countries including their families for some purposes, but mostly it is due to financial reasons (Kageyama, 2008; Kelman \& Khan, 2012). Also, they intend to gain an international education experience abroad. Researchers from sociology, demography, economics, geography and anthropology disciplines have studied many aspects of migration, which conclude that people migrate from one place to other countries are to fulfil their economic needs (Liang, Li, \& Ma, 2013). Then, according to Sinha, Jha and Negi (2012), women's empowerment is emerging as an important indicator of the development of a society, as well as an indicator of the status of women in that society (Sinha, Jha, \& Negi, 2012). As such, the woman migration has been considered to be the trend for people living in developing nations.

Several developing countries are trying to move from home countries to other nations due to financial need (Ackah \& Medvedev, 2012). In Bangladesh, international migration is considered a male preserve, with women's migration restricted to a small minority within the professional classes (Blanchet \& Watson, 2019). It means that international migration is only carried out by male because females in Bangladesh find difficulty to migrate. Furthermore, in a study of Japanese women migrants to Australia, Hamano (2014) concluded that migrants undergo some form of downward social mobility in the course of settling in a new country (Hamano, 2014). Although there could be plenty of reasons why people migrate to other countries, generally they need to fulfil their daily needs and specially to face their financial issues. As a result, it probably can be said that the main purpose of migration from area to other countries is to get financial needs.

When it comes to Indonesia, women's emigration is a 
common phenomenon that occurs in developing countries such as Indonesia (Hugo, 1995). Research into women's emigration in East Nusa Tenggara, reveals shifting subjectivity and changing relations with family and local communities, as well as participation in economic spaces (Williams, 2007). This is because, the main reason why people migrate from Indonesia to other countries is to survive economically for their family. In addition, the economic situation of the family forces women to work to fulfil family needs and to solve their financial problems (Hugo, 2000). Some experts argue that the current era of globalization makes it difficult to find work locally, especially for women (Hugo, 2002). Therefore, the factors that influence women's emigration from villages to foreign countries vary, however helping the family economy is a key motivator to migrate from their home countries to developed nations (Yazid, 2015).

Ullah (2017) reveals that women have traditionally been at a disadvantage in many countries in the world as strong patriarchal tradition often impinges the rights of women (Ullah, 2017). Regarding this issue, there are four main reasons why women often become the person who migrate to other countries for the purpose of financial needs. Firstly, the difficulty of economic condition in Indonesia causes people to be jobless, either for male or female (Irawaty \& Wahyuni, 2011). They tend to work with the hard job such as building construction, and others. As such, the unskilled people cannot get the proper job for their day-to-day needs. This circumstance cause difficulty in the economic needs, especially for the family to fulfil their basic need and also forced women to work and help their families.

Secondly, some available jobs for unskilled person, especially women only become household or family assistance (Astuti, 2018). It is because women can only work with some activities which are not really hard. For example, women can be home cleaner, childcare, home care, and many other jobs which are available for those who do not have advance skills and low-level education (Irawaty \& Wahyuni, 2011). However, some mentioned jobs in Indonesia are considered to be low salary. Although they will get paid from their employer, they only earn under minimum standard wage (Williams, 2007). This difficult situation forces some women in Indonesia to find out on how to fulfil their basic need and earn a wide range of salary (Irawaty \& Wahyuni, 2011). As such, one of the options to solve this difficulty is migrated to developed nations which have high different currency with Indonesia.

In addition, people living in the countryside of Indonesia has often become a targeted group by worker agency since there are very limited jobs available in rural areas (Williams, 2007). They ask local people especially women to leave their family and work in abroad. Usually, Indonesian woman worker moves to Malaysia, Taiwan, Saudi Arabia and some middle east countries which have higher currency than Indonesian Rupiah (Irawaty \& Wahyuni, 2011). They can get more than four million rupiah every month as their salary per month, in which this is very high salary compared with working to be household in Indonesia. Therefore, limitation of job availability can be other options why people migrate from one place to others (Hussin, 2013).

What is more, West Java Province in Indonesia is one of the highest regions which brings their women migrate to other countries for the economic purposes (Hussin, 2013). In terms of statistical council agency of West Java Province, in 2016, overall there were 61.239 people who work abroad (Indonesia Statistical Council, 2018). Mostly, they come to Taiwan to earn more money for their daily need. The number of people migrating to this country accounted for 22.847 people (Indonesia Statistical Council, 2018). In addition, Subang is one of the regions located in West Java Province, so that it is interested to see the migration movement from Subang.

The woman migrating abroad for working have a fixed term contract. It means that they will probably go back to the home country to develop and use their income for business. Generally, the salary obtaining from abroad would be used to create private business so that it will be empowered sustainably (Yazid, 2015). As such, the issue of empowerment is important. Based on the above discussion, the research questions are (1) what is the economic empowerment carried out by Indonesian women worker in Subang Regency after migration? (2) how the remittance is being used by Indonesian women workers in Subang regency after migration? (3) what is the role of Indonesian women workers towards empowering local community in Subang regency after migration?

\section{Literature Review}

\subsection{Concept of Education Empowerment}

Empowerment is considered to be one of important aspect towards community. This is because it can help some local communities to improve their quality of life in terms of economic empowerment. Since the issue of empowerment has been recognised by international communities, women's empowerment is a part of Sustainable Development Goal (SDG) (Malapit, et al., 2019). Women's empowerment is inseparable from empowerment of the community. More specifically, women's empowerment aims to improve the quality of the surrounding community, so that an educated society is created (Babari \& Prijono, 1996; Pandey, Lama, \& Lee, 2011).

A key element of empowerment is participation in economic activities (Sell \& Minot, 2018). Economic activities can be recognised by improving local communities by women who have migrated back to their home countries. For example, they can establish their local enterprises, small business company, and any others 
business which are inspired by other countries (Miedema, Haardorfer, Girard, \& Yount, 2018). As such, this can be some advantages either for women after migration or the local communities to improve their economic life.

In general, the concept of women's empowerment can be identified as an effort carried out by a group of women or individually, to enable improvement in the quality of life and capabilities of the surrounding community (Stromquist, 2015; Ramanayake \& Wijetunga, 2018). The process of empowering women can be achieved through education or working abroad, in order to gain the skills and abilities to develop themselves and their surrounding environment. The right to obtain literacy is also one way to empower women (Eldred, 2014; Sharma \& Gambhir, 2017), therefore the concept of empowerment can be carried out through the education process. Women's empowerment is conceptualized and operationalized largely in Classic Patriarchal settings (Miedema, Haardorfer, Girard, \& Yount, 2018). Another opinion reveals that empowerment is a concept carried out by individuals who know a group of people to be able to prepare themselves and their future (Kageyama, 2008). The concept of individual empowerment is defined by a person being able to continue to learn and improve, in order to manage personally and support a family, now and in the future (Irawaty \& Wahyuni, 2011).

The concept of empowerment encompasses developing and improving quality, and empowering a community around it (Dhar, 2012). In India, women are considered as a lower class. Indian women are disadvantaged in areas such as finance, education, and the economy. The empowerment process would ensure women are not left behind and would improve the quality of their lives (Gul, 2015; Bhat, 2015; Porter, 2013). Based on the three concepts above, it can be concluded that empowerment is an effort to increase the capacity and capability of both a person, and a group of people, so that their lives are better.

In Vietnam, intimate partner violence is an important social issue that policy makers seek to address by a variety of interventions, including efforts to promote women's empowerment (Bulte \& Lensink, 2019). Women's empowerment is increasingly considered as a strategy to enhance household security and nutrition in Tanzania (Galie, et al., 2019). Women's empowerment can be achieved through an awareness process, so that women are able to critically analyse the situation of the community, are able to identify discriminatory practices which are social constructs and can distinguish between natural roles and gender roles.

The aforementioned evidence revealed that the concept of empowerment has several positive developments. These are improving their local community, especially in terms of economic development. It also helps improve small business enterprises across the world, so that it is imperative to develop and build some empowerment particularly for women.

\subsection{The Concept of International Migration}

Emigration is defined as the movement from one place to other areas. It can be cross the city, across the island, or move to other countries (Ramanayake \& Wijetunga, 2018). Basically, there are a wide range of reasons why emigration happens in this contemporary era. Firstly, they might migrate due to natural disaster such as landslides, earthquake, tsunami, and other disasters. Some experts argue that the purpose of people moving from their original place of residence to other areas is to discover a safer location (Kelman \& Khan, 2012; Ackah \& Medvedev, 2012), although the main reason for emigration is to seek a better life. While emigration can relate to movement within national boundaries, this study focus on international emigration by a person or group of people from Indonesia to abroad, especially women's emigration.

There are many main factors that will influence a person or group of people to carry out the process of moving from one country to another, including climate change, weather, the economy, education, and globalization (Rapoport, 2016; Astuti, 2018). Women's involvement in the migratory process appears to have a generally empowering impact on them in terms of higher self-esteem and also as economic actors (Ojong \& Muthuki, 2010).

The number of women migrations for leaving their home countries and move across the nation has increased over the years. Some possible factors which might happened from this condition are filling their spare time, prestige, and increasing status in the eyes of their husband, family and society (Gul, 2015). The strength of the family is a key mechanism to enable a positive influence on intentions to emigrate (Piracha \& Saraogi, 2017). What is more, Indonesian women who choose to work abroad are paid higher salaries compared with those working domestically. When remittances are motivated by altruism, the migrant also takes into consideration the welfare of members of the family as a factor, subjectively weighted, in the utility function (Lianos \& Pseiridis, 2014).

On the other hands, there are four main conditions in Indonesia which have forced and attracted women to migrate and work in other countries. Firstly, the majority of Indonesian workers who choose to go abroad for working is that they have a huge debt either to individual or institution (Hussin, 2013). People are mostly in due to pay their debt, such as home mortgage, or other money which should be paid quickly (Haris \& Azizah, 2018). Then, they are looking for the job which can earn a lot of money with a low level of education (Hussin, 2013). After they found that working abroad can obtain a lot of salary due to different currency, they directly decided to work abroad.

The second reasons why people move to developed country is a low level of education (Hussin, 2013; Astuti, 2018; Williams, 2007). In Indonesia, a wide range of employer required high school level as the minimum education requirement or the students graduated from vocational high school (Yazid, 2015). This is because 
vocational high school alumni are being equipped with specific skills such as information technology, accounting, graphic design, and many other skills which are beneficial for looking for jobs. However, for those who are just graduated from elementary school and junior high school will find difficulty getting a proper job (Haris \& Azizah, 2018). This circumstance forced women to migrate to other countries to get some jobs and earn more money.

The third condition which make them to work in other countries is an increasing day-to-day need especially in terms of financial (Yazid, 2015). They argue that their everyday need increases over the year, and it was not followed by their income (Astuti, 2018). For example, when people have a new baby born, they need additional income to fulfil their live (Williams, 2007). This condition encourages women to help their husband to work abroad since they think that they will obtain higher salary when they work abroad.

Finally, the influence and motivation from successful women being Indonesian women workers has been another reason. People see other women coming to Indonesia and bringing a wide amount of money for buying a home, creating a small business enterprise, buying a car, and other successful symbol as a successful woman worker (Irawaty $\&$ Wahyuni, 2011). These condition makes several women who have their lower level education to work abroad and earn more salary, even as a household.

\section{Methods}

\subsection{Research Design}

The study used a mixed method designed by combining quantitative and qualitative methods (Creswell, 2017). There are two reasons why mixed method were used for this research. Firstly, the quantitative method made it easy to get participant's respond quickly since they just need to fill in the questionnaire. Then, the data analysis was less-time consuming because the analysis was helped by SPSS software. However, the questionnaire makes it difficult to get the reason, so that qualitative method by using interview was being used (Cohen, Manion, \& Morrison, 2007). The interview can provide an in-depth data and rich information about the reasons, experiences, feeling of Indonesian women worker after migration. According to Biesta (2012) the combination of both qualitative and quantitative research methods will deliver more reliable results (Biesta, 2012). Mixed method research can also help researchers to obtain overall results regarding the experiences of participants (Mertens, 2014).

Descriptive statistic was used to analyse the data. It shows the average of participants' responds to questionnaire, particularly mean, modus, median and standard deviation. The analysis also used SPSS software because the software made it less-time consuming (Mujis,
2010). In addition to data analysis, content analysis was used to analyse the interview data.

\subsection{Participants}

The participants of this study are women who were migrating to other countries for the economic purposes. Based on the literature review, the participants were selected who are deciding to go abroad due to fulfilling their day-to-day life, having economic difficulties due to debt towards other people or institution, having a low level of education, and also those who were motivated to earn more money (Haris \& Azizah, 2018; Ananta, Kartowibowo, Wiyono, \& Chotib, 1998). The number of participants who were selected on this study was 45 women. A detailed participants' characteristic would be displayed below:

Table 1. Participants characteristic based on age

\begin{tabular}{|c|c|c|}
\hline Ages & Frequency & $\mathbf{\%}$ \\
\hline $17-25$ years old & 10 & 22,2 \\
\hline $26-50$ years old & 25 & 55,6 \\
\hline $51-75$ years old & 10 & 22,2 \\
\hline
\end{tabular}

Table 2. Participants characteristic based on education level

\begin{tabular}{|c|c|c|}
\hline Education level & Frequency & $\mathbf{\%}$ \\
\hline Unfinished primary education & 10 & 22,2 \\
\hline SD (Primary education) & 20 & 44,4 \\
\hline SMP (Junior High School) & 5 & 11,1 \\
\hline SMA (Senior High School) & 10 & 22,2 \\
\hline
\end{tabular}

Table 3. Participants characteristics based on country destinations

\begin{tabular}{|c|c|c|}
\hline Country destination & Frequency & $\mathbf{\%}$ \\
\hline Middle east country & 25 & 55,6 \\
\hline East Asia & 10 & 22,2 \\
\hline Malaysia & 10 & 22,2 \\
\hline
\end{tabular}

In terms of the Table 1, it can be seen that the majority of participants were at the age of above twenty-six years old, while the younger women were only three persons. In addition to this, based on Table 2, women who only hold primary education level were higher than other participants, which was about 6 persons. It was followed by those who even did not completed their primary education. Finally, most of women from Subang regency decided to choose Middle east country as it has the highest percentage compared with other country destinations.

The participants were chosen by snowball sampling technique. This technique help researchers to get a wide variety of participants about women empowerments (Cohen, Manion, \& Morrison, 2007). The snowball sampling started by identifying several women who had an experience of migration abroad for the purpose of economic improvement. At the first time, the first participants were interviewed and gave more data about 
women empowerment in Subang Regency, West Java. Then, after the data obtained from the first participants, she was asked and showed other women who might be available to be the next participants. After getting the person chosen by the first participants, then we go to the next participant until we get 45 persons.

\subsection{Instruments and Data Collection}

The research instrument used in this research was questionnaire. There are overall 45 questions. The first part of the questionnaire was a background which consists of participants age, education level, current activities and marital status. Likert-scale questions were used to understand the reasons why women workers decided to move abroad, including the economic empowerment, and the use of remittance when women workers came back to Indonesia. There are also open-ended questions regarding how they empower local community, so that women workers have an influence on community.

A pilot survey was used to analyse the questionnaire. It was crucial for the research because it would give a wide range of opportunities for the results (Cohen, Manion, \& Morrison, 2007). A pilot survey was undertaken towards two experts, which are lecturer from Geography department in Indonesia. It was used to check the clarity of the questionnaire items, instructions and layout. It also gained feedback on the validity and reliability of the questionnaire. Finally, pilot instrument was also used to check readability levels for the target audience (Cohen, Manion, \& Morrison, 2007).

In addition to the questionnaire, interview was also used since the use of questionnaire does not explain the reason about their answer, then semi-structured interview was being used to get the deep information about these three research questions generally (Biesta, 2012).

\subsection{Data Analysis}

After conducting the research, there are two main ways of data analysis since it was used a mixed-method design. Firstly, descriptive statistics was used to analyse and present the data. Since there are a lot of questions in the questionnaire, SPSS statistical software was used to easy the process of data analysis (Creswell, 2017). All 45 data were presented by using graph so that it will create the results to be easy to understand. However, since the questionnaires data is not enough, interview was being conducted to get detail about their reason (Creswell, 2017).

In addition to data analysis, content analysis was used to analyse the interview. The interview text was transcribed and analysed by using open coding, axial coding and selective coding to analyse the women workers response towards economic empowerment, the use of remittance and empowering local community. NVivo software was used to analyse the data after the recorded voice was transcribed.

\section{Findings}

The findings of the study showed that there are three main results of this research. It could be divided into three main parts, which are women workers economic empowerment after migration, the use of remittance from abroad, and how local communities are empowered by women workers after migration.

\subsection{Economic Empowerment of Women in Subang}

Economic empowerment is considered to be some women workers activities after returning home which are productive to earn more money (Dhar, 2012). Usually, some women workers earn a lot of money because the experiences or the ideas that they get from abroad are applied in their home country. It is important to know the women empowerment because they can also earn more money to raise their families. The results showed that trading and teaching Arabic language are considered to be the main women workers economic empowerment in Subang after migration.

\section{Division of Work}

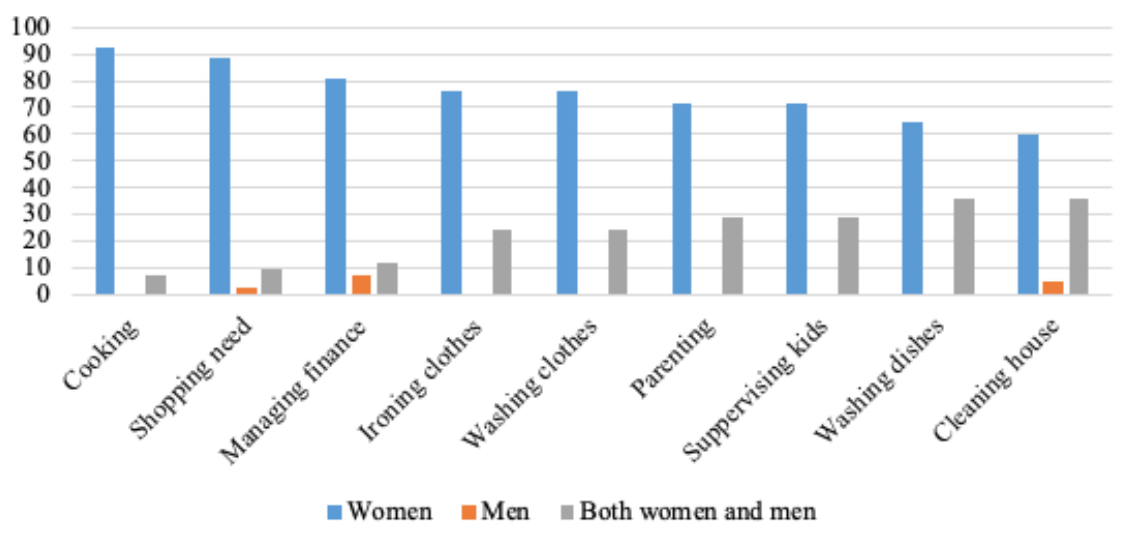

Figure 1. Percentage of Profile of Household Activities 
Firstly, several participants argue that they are trying to use cooking skill to improve their economic empowerment after migration. As seen in figure 1, cooking experiences are higher percentage activities of women after migration. During working in middle east country, usually women workers were asked to cook the local cuisine such as Kebab, Biriani rice, and other food. Then, when they return to their home country, women workers are trying to cook the same food and sell it to their neighbours. Therefore, women workers can earn more money although they have returned to Indonesia. This result has been confirmed by one of participants.

“...usually, I cook Biriani Rice and gulai chicken in Indonesia, but I tried to make it spicier since Indonesian are more likely to eat spicy food. Then, I sell the food to neighbours, for the purpose of earning money. During Islamic celebration day such as Idul Fitri and Idul Adha, I can earn more money as people order a lot of food from me..." (W13, interview, 2018)

It shows that although women workers have returned back to Indonesia, at least they have some experiences and cooking skills which can be used to cook middle east food and sell it in Indonesia. This situation can help Indonesian women worker to increase their economic life after migration.

Apart from cooking, women workers also become trader. In this study, the majority of women sell mukena (women prayer cloth). Participants claimed that trading is a productive activity that can be undertaken at home, therefore allowing women to continue with the obligations of the reproductive role. As respondents have a large responsibility as head of the family, they contribute to the fulfilment of family clothing.

"... if Eid Mubarak likes to be given mukena (prayer clothes for women), sometimes it is for the mother of the boss's husband. Or given by children who have worked, mothers rarely buy themselves ... "(W1, interview, 2018)

The participants showed that selling mukena (a muslim praying cloth) is beneficial and they can earn more money. This is based on the people who were interviewed that selling can be their additional activities and it can help improve their day-to-day needs.

Secondly, some other participants have a new language skill and it is considered to be one of a new powerful skill to improve the economic empowerment. The majority of participants who have come back from middle east country are able to speak Arabic language. It is probably because the language was being used for their daily activities after migration. When they return to their home country, they used the language for teaching other women workers who have an intention to go abroad.

“...I learned Arabic language during pre-departure training. However, it was not significance since I still did not understand what my boss said in the country. My language skill was improved during living in middle east country as I used it as my day-to-day activities..." (W15, interview, 2018)

The language ability of participants varies. Some of participants argue that they almost forget about the Arabic language skill learned from abroad. However, some of them are still remember, so that they open Arabic Language course for beginner. They teach English either for their neighbours, kids, or other people who need Arabic language.

“...I teach Arabic language for my neighbours' kids. They intend to go to middle east for working as well. However, it was not regular teaching, maybe it was only twice in a week. Sometimes if they feel lazy, the class was skipped..." (W2, interview, 2019).

It can be seen that language ability can be another economic empowerment because women worker can earn money in their home country by teaching Arabic language skill. In addition, for those who work in Malaysia, they do not have any language barrier since Malaysian language is slightly similar to Indonesian language.

All in all, although Indonesian women workers have returned to their home country, the economic empowerment can be undertaken to some extent. They can sell middle east food such as mukena, gulai chicken, Biriani Rice and Kebab. These sorts of food can be sold to their neighbour. In addition, women workes also can get language skill and it can be used to teach other people to earn more money.

\subsection{Utilization of Remittance for Women after International Migration}

Remittance can probably be defined as sending people's earning from the place where they work, and it could be some money, goods, or other things as a result of working abroad. It is common when women worker migrates to other countries for the purpose of fulfilling their economic needs. Martha explained that apart from goods and money, the remittance can also be ideas, knowledge, and new experiences which are gained while working in other countries. So that, it can be the main benefit for women to work abroad. This section would show the results of how Indonesian women worker used their remittance after working abroad.

Working abroad can be exhausting for some women workers. It is because they should probably work in days and nights every day, even they do not have time to socialize and meet their friends. Women workers should be able to serve the whole families in the middle east. Although it can be tiring, they still work to earn more money. These are some examples of women workers experience when they live abroad for being Indonesian women workers.

The results showed that the majority of women workers used their remittance for their primary and secondary need. 
Firstly, Indonesian women workers argue that fulfilling their daily need would be the main purpose of sending the remittance. It could be for food, drink, and their children need. Otherwise, some women worker used their remittance for their secondary need such as marriage fee, health and paying debt.

Secondly, after their primary and secondary need have been achieved, they put the remittance to the investment instruments such as gold, land, rice field, and livestock. However, the remittance allocated towards investment instruments is not as higher as primary and secondary need. Indonesian women workers need a lot of time to buy land for the investment. Finally, some of them used the money for creating their own business.

"...I have ever used the money for creating my own business and put the money to my relatives regularly. The purpose of business is to make it sustain, so that I can still earn money after I work in middle east. However, the money which was used for business was failed and I was disappointed. Finally, I send the money to my son to fulfil their daily need..." (W12, Interview, 2018),
Education is considered to be utterly important for the majority of women workers. They spend several amounts of money to the school, so that their children can go to school. They believe that investment in education is important for the future, particularly for their family. They also argue that remittance is the main income for education, although they have husband who can earn money as well.

"... my husband's salary does not enough to pay tuition fee. So my income was used to pay tuition fee. Also, sometimes my parents and my relatives need additional money, so I sometimes send the remittance to my parents and my brother..." (W10, Interview, 2018)

The figure showed that the majority of women workers spent their remittance for their consumption or day-to-day need which was accounted for $73 \%$. Then, in contrast, only $23 \%$ of women workers who put tuition fee or spending money for education was considered to be important. It can be concluded that primary need is probably considered to be important for Indonesian women workers, particularly in Subang regency.

\section{The usage of remittance}

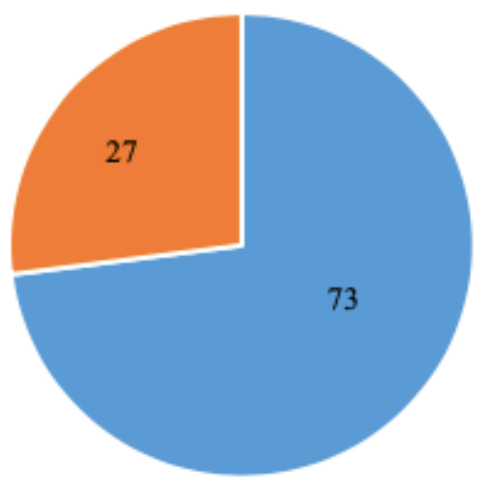

- Consumption, Tuition fee, Investment $\quad$ - Tuition fee, consumption and investment

Figure 2. The usage of remittance 


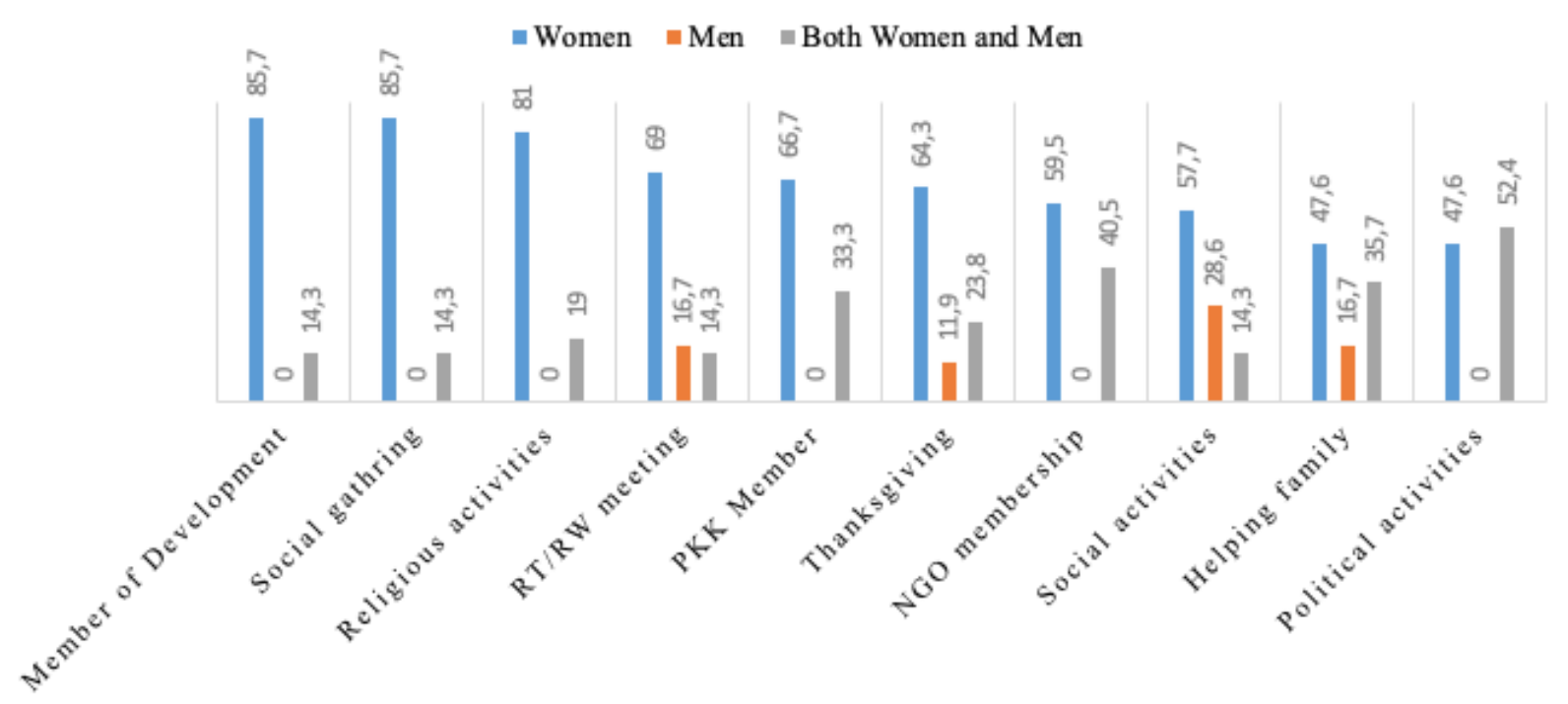

Figure 3. The Role of Women in Social Activities

\subsection{The Role of Women in Empowering Local Communities}

The third women workers activities is empowering local communities. Several women workers after migration from abroad, have some responsibilities to empower their local communities because they have several experiences abroad. These social activities are considered outside of reproductive and productive activities. Some activities which are part of social empowerment are RT or RW activities, community service, social gathering, recitation, thanksgiving, helping with neighboring events, political activities, community empowerment activities, becoming a member of a formal institution, and being a chairperson in an institution.

Figure 3 shows the distribution of the social roles of the respondent's families. It can be seen that the most common activity is being a participant in empowerment and social gathering programs. In contrast, being part of political work is some activities in which the majority of women does not like. Women in general were also more active in community activities than men such as attending neighbourhood Association meetings, becoming a member of the Family Welfare Development called PKK, participating in activities in an institution, and volunteering.

"My mom is also a cadre; she likes to join in Posyandu with PKK, and sometimes help Posyandu activities". (W6, interviewed, 2018)

"I felt it is good experience. Because I also like to read every Tuesday together with other mothers" (W7, interviewed, 2018).

"In Posyandu there is a routine recitation. If you usually take part in the evening recitation with devotional work, that is also if you are at home. "(W9, interviewed, 2018),"
The role of women in the social sector does not spread evenly. Respondents collected are at a score of 12.5 , which means that in the respondent's family the social role done independently by the majority of women is in the highest value. Empowerment activities are in fact given first to women who are active in social activities. The field facilitator thinks that women who are active in social activities in their environment will be more responsible for empowerment programs.

In conclusion, although there are a lot of social empowering activities, the majority of woman support posyandu (a healthcare centre) and social gathering with other people, while political activities were avoided by ex-women workers. Although they can earn a lot of money from middle east countries, they still care for their neighbour community.

\section{Discussion}

The findings of this study revealed that ex-women workers from abroad generally improve the quality of life, particularly in terms of economic life and community empowerment. This part will discuss, compare and contrast about economic empowerment by women workers, and how they use the remittance and local community empowerment.

Some previous studies in Indonesia have confirmed that the factors which force Indonesian woman to work abroad, particularly middle east are economic difficulty, low-level education, low salary, increasing the day-to-day need financially and being motivated by successful women migrants (Ananta, Kartowibowo, Wiyono, \& Chotib, 1998; Astuti, 2018; Haris \& Azizah, 2018). Comparing with other countries, this circumstances are almost similar, such as in Vietnam, Nepal, India and Bangladesh, as they move 
abroad to earn more money and get increase in their salaries with low-level education (Bulte \& Lensink, 2019; Pandey, Lama, \& Lee, 2011; Bhat, 2015). However, after returning to their home countries, generally the women workers have improved their quality of life slightly. The most important thing is that they have some skills which can sustainably support financially such as providing some service for other people and selling goods which can improve their economic life financially (Rapoport, 2016).

Economic empowerment is considered to be women's economic activities after they return home. This is common across all women workers when they come back to their home countries. Generally, across the world, economic empowerment is divided into two main parts, which are reproductive and productive activities (Bhat, 2015; Kageyama, 2008; Sell \& Minot, 2018).

In Indonesia, particularly in Subang, the majority of ex-woman workers from abroad undertake cooking as their main activities after returning home. Cooking can be the main economic empowerment because some women workers can sell some middle east food such as Kebab, Biriani Rice, Gulai chicken and mukena (women prayer cloth). This result has confirmed the previous study in Indonesia which showed that some household activities such as cooking has become women work when they come home (Hugo, 2002). Apart from selling goods, teaching arabic languange for other people can also earn money. The results are similar to the study undertaken in other part of Indonesia, which revealed that selling some goods and being trader and teaching languange are women's main activities after they return home (Astuti, 2018; Yazid, 2015).

In terms of the use of remmitance, the majority women workers argue that it would be used to fulfil their day-to-day need, since they send the money home regularly during, they work in abroad (Hamano, 2014). There are some variety forms of remittance usage after they return home. In some countries, the remittance was used to spend for educational purpose, such as for their children, since they argue that education is important to their family (Kelman \& Khan, 2012; Lianos \& Pseiridis, 2014). Other people argue that some remittance is being used for buying a house and investing their money for the future need (Dhar, 2012; Bhat, 2015). However, there are different results of this study which shows that the participant's remittance is used for day-to-day need, education purpose, serving their parents who are getting sick, and also for building home as well as for investment. The participants also send regularly the remittance to their home countries during the period of migration. The results have confirmed that in Indonesia, women workers used their money for family need (Yazid, 2015; Williams, 2007; Ullah, 2017).

Finally, the majority of ex-migration women have some responsibility to empower local community. It has been common activities in Indonesia to improve the quality of local economy by sharing and learning together (Hussin,
2013). The previous study in Indonesia revealed that some of ex-woman workers, after they return home, they become Arabic language teachers in Indonesia (Astuti, 2018). They said it is their responsibility because they have a language skill and they want to share the skill towards others. However, in this research, the majority of participants follow community service and social gathering, or commonly called arisan. During gathering, they share their experience towards other women and guide them step by step on how to work abroad.

\section{Conclusions and Implication}

Women's migration to other countries is a common phenomenon that occurs in developing countries like Indonesia. In order to support the family, many women must emigrate to find work. They generally move to other countries due to three main reasons. Firstly, they have financial problem to fulfil their day-to-day need. Although they work in Indonesia, but the salary does not support fully their daily need. Secondly, the majority of women decide to migrate to other countries were due to low level education, which cause them difficulty getting a job. Mostly, women from low level education tend to work as the household or babysitter. However, the expected salary does not meet their daily need, so that they decide to work abroad. Finally, some other women chose to migrate to other countries because of motivation from some successful people who returned home. They can buy a house, some land, cars, rice fields and others, so that they also intend to be successful financially.

After women return home, in terms of economic empowerment, there are a wide range of activities, which are selling and teaching foreign language. The most common economic empowerment activities are selling food since cooking is the main activities during women work abroad. For example, they sell Kebab, Biriani Rice, and gulai chicken. In addition, some of women sell mukena (women praying cloth). In addition to the economic empowerment, several Indonesian women workers who return from middle east country teach Arabic language for beginner so that they can earn money.

In terms of the usage of remittance, it is often used by the family to open a business in order to seek additional income, and to meet their daily needs. Remittance sent to respondent families in Subang by women emigrants were allocated to meet consumption, education, economy, and production needs. The utilization of remittance in the form of skills investment is still low, with only a few ex-migrant women who try to improve their skills in areas of interest. Skills investment appears to be influenced by the country where the respondents once worked. For example, social investment (donations for village development) was not undertaken by respondents who had worked in Hong Kong. The use of remittances by migrant families in Subang focus 
on meeting educational consumption and investment needs.

Finally, as for the social empowerment, the majority of woman workers help to develop posyandu. This place is a healthcare centre for people living in some villages. The Indonesian women migrations were trying to support financially. Furthermore, social gathering was considered to be another activity of women in Subang regency as a result of migration.

Although this research has been done, it might face some potential limitations. Firstly, the participants are only 45 women workers, which might not enough to generalise the results. This is because the difficulty in finding some women who are available to be interviewed for this research. Furthermore, some participants do not intend to answer some questions, especially about financial problem and the use of remittance. They said use of remittance is considered to be their privacy, so that it cannot be explored deeply. As such, further research must cover the representative of Indonesian women workers from all province, so that it will have a wide variety of results. Also, the future research might focus on the use of remittance, because this part to some extent, can change and improve the quality of life for the people. So that, it is interesting to be investigated in a separate way.

The implication of this research would be divided into two main parts. Firstly, for the government, particularly in Subang regency, it helps inform the general women workers behaviour in Subang. It can also be the literature for the people who will undertake some research in Indonesia. Then, generally, the experience can be used as the measurement when they intend to work abroad.

\section{Acknowledgment}

We are very grateful to experts for their appropriate and constructive suggestions to improve this template.

\section{REFERENCES}

[1] Sinha, B., Jha, S., \& Negi, N. S. (2012). Migration and empowerment: the experience of women in households in India where migration of a husband has occurred. Journal of Gender Studies, 21(1), 61-76.

[2] Liang, Z., Li, J., \& Ma, Z. (2013). Migration and remittance: Evidence from a poor province in China. Asian Population Studies, 9(2), 124-141.

[3] Blanchet, T., \& Watson, S. K. (2019). Learning to Swim in Turbulent Waters: Women's Migration at the Agency-Exploitation Nexus. Journal of Contemporary Asia, $1-21$.

[4] Hamano, T. (2014). Japanese Women Migrants in Australia: Situating the Self between Ethnicity and Femininity. Asian and Pacific Migration Journal, 23, 211-228.

[5] Hugo, G. (1995). International Labor Migration and the Family: Some Observations from Indonesia. Asian and Pacific Migration Journal, 4(2-3), 273-201.

[6] Williams, C. (2007). Women's mobility, changing gender relations and development in East Nusa Tenggara, Indonesia. sian and Pacific Migration Journal, 16(4), 533-554.

[7] Hugo, G. (2000). The crisis and International population movement in Indonesia. Asian and Pacific Migration Journal, 9(1), 93-129.

[8] Hugo, G. (2002). Effects of International migration on the family in Indonesia. Asian and Pacific Migration Journal, 11(1), 13-46.

[9] Yazid, S. (2015). Indonesian labour migration: Identifying the women. Global \& Strategis, 9(1), 49-62.

[10] Ullah, A. A. (2017). Male migration and 'left-behind' women: Bane or Boon? Environment and Urbanization Asia, 8(1), 59-73.

[11] Malapit, H., Quisumbing, A., Dick, R. M., Seymour, G., Martinez, E. M., Heckert, J.,... Yount, K. M. (2019). Development of the project-level women's empowerment in agriculture Index (Pro-WEAI). World Development (122), 675-692.

[12] Babari, J., \& Prijono, O. S. (1996). Pendidikan Sebagai Sarana Pemberdayaan. In O. S. Prijono, \& M. Pranarka, Pemberdayaan Konsep, Kebijakan dan Implementasi (pp. 71-96). Jakarta: Center for Strategis and International Studies.

[13] Pandey, S., Lama, G., \& Lee, H. (2011). Effect of women's empowerment on their utilization of health services: A case of Nepal. International Social Work, 55(4), 554-573.

[14] Sell, M., \& Minot, N. (2018). What factors explain women's empowerment? Decision- making among small-scale farmers in Uganda. Women's Studies International Forum (71), 46-55.

[15] Stromquist, N. P. (2015). Women's Empowerment and Education: linking knowledge to transformative action. European Journal of Education, 5(3).

[16] Ramanayake, S. S., \& Wijetunga, C. S. (2018). Sri Lanka's Labour Migration Trends, Remittances and Economic Growth. South Asia Research, 38(3S), 61S-81S.

[17] Eldred, J. (2014). Literacy and women's empowerment. hamburgh: UNESCO Institute for Lifelong Learning.

[18] Sharma, S., \& Gambhir, D. (2017). The 'BIBA' Woman of India: A Model for Women Economic Empowerment. South Asian Journal of Business and Management Cases, 6(1), 89-99.

[19] Miedema, S. S., Haardorfer, R., Girard, A. W., \& Yount, K. M. (2018). Women's empowerment in East Africa: Development of a cross-country comparable measure. World Development (110), 453-464.

[20] Kageyama, A. (2008). Extent of Poverty Alleviation by Migrant Remittances in Sri Lanka. South Asia Research, 28(1), 89-108. 
[21] Irawaty, T., \& Wahyuni, E. S. (2011). Migrasi Internasional Perempuan Desa dan Pemanfaatan Remitan di Desa Pusakajaya, Kecamatan Pusakajaya, Kabupaten Subang, Provinsi Jawa Barat. Sodality: Jurnal Transdisiplin Sosiologi, Komunikasi, dan Ekologi Manusia, 5(3), 297-310.

[22] Dhar, R. (2012). Women and International Migration: A Cross-cultural Analysis. Social Change, 42(1), 93-102.

[23] Gul, S. B. (2015). Women and Violence: A Studi of Women's Empowerment and Its Challanges in Jammu and Kashmir. Reviews of Literature, 2(7).

[24] Bhat, R. A. (2015). Role of Education in the Empowement of Women in India. ournal of Education and Practice, $6(10)$.

[25] Porter, E. (2013). Rethinking Women's Empowerment. Journal of Peacebuilding \& Development, 8(1), 1-14.

[26] Bulte, E., \& Lensink, R. (2019). Women's empowerment and domestic abuse: Experimental evidence from Vietnam. European Economic Review, 115, 172-191.

[27] Galie, A., Teufel, N., Girard, A. W., Baltenweck, I., Salas, P. D., Price, M. J., . . . Yount, K. L. (2019). Women's empowerment, food security and nutrition of pastoral communities in Tanzania. Global Food Security (23), 125-134.

[28] Kelman, I., \& Khan, S. (2012). Tracking a moving target of migration: island perspectives. Disaster Prevention and Management: An International Journal, 634-639.

[29] Ackah, C., \& Medvedev, D. (2012). Internal migration in Ghana: determinants and welfare impacts. International Journal of Social Economics, 764-784.

[30] Rapoport, H. (2016). Migration and globalization: what's in it for developing countries? International Journal of Manpower, 1209-1226.

[31] Astuti, T. M. (2018). The Ever Failing Counter Movement: The Case of Low Class Women Migration at Grobongan, Central Java. Humaniora, 123-135.

[32] Ojong, V. B., \& Muthuki, J. M. (2010). Empowerment or reconstituted subordination? Dynamics of gender identities in the lives of professional African migrant women in South Africa. Journal of Social Sciences, 25(1), 169-176.

[33] Piracha, M., \& Saraogi, A. (2017). Remittances and migration intentions of the left-behind. Migration and Development, 6(1), 102-122.

[34] Lianos, T. P., \& Pseiridis, A. (2014). I trust, therefore I remit? An examination of the size and motivation of Remittances. Journal of Ethnic and Migration Studies, 40(4), 528-543.

[35] Creswell, J. (2017). Research design, qualitative, quantitative and mixed methods approaches. London: Sage Publication.

[36] Ivankova, N. V., Creswell, J. W., \& Stick, S. L. (2006). Using mixed-methods sequential explanatory design: from theory to practice. Field Methods, 18(1), 3-20.

[37] Biesta, G. (2012). Mixed methods. In J. Arthur, Research methods and methodologies in education. SAGE Publication.
[38] Mertens, D. M. (2014). Research and evaluation in education and psychology: Integrating diversity with quantitative, qualitative, and mixed methods. SAGE Publications.

[39] Mujis, D. (2010). Doing quantitative research in education with SPSS. SAGE Publications.

[40] Cohen, L., Manion, L., \& Morrison, L. (2007). Research methods in education (7th edition). Routledge.

[41] Hussin, M. H. (2013). Factors Influencing Indonesian Women Becomes Migrant Workers. Jurnal Hubungan Internasional, 2(1), 64-74.

[42] Indonesia Statistical Council. (2018, March 3). Indonesia Statistical Council. Retrieved from The number of women jobseeker based on education level in West Java Province: https://jabar.bps.go.id/statictable/2018/03/09/290/jumlah-p encari-kerja-perempuan-menurut-tingkat-pendidikan-yangditamatkan-di-jawa-barat-2015.html

[43] Haris, A., \& Azizah, S. N. (2018). International Mobility Based on Women Labour: Study of Change in Socio-Economic-Cultural Family Former Migrant Worker Jakatawa Bulaksari in The Village, District Bantarsari, Cilacap Seen from the Perspective of Islamic Economic Theory. Ijtimā'iyya, 3(1), 129-149.

[44] Ananta, A., Kartowibowo, D., Wiyono, N. H., \& Chotib. (1998). The Impact of the Economic Crisis on International Migration: The Case of Indonesia. Asian and Pacific Migration Journal, 7(2-3), 313-338. 